\title{
A STUDY ON DNA FINGERPRINTING OF AREOLATED GROUPER (Epinephelus areolatus) USING RAPD ANALYSIS
}

\author{
Andi Parenrengi"), Lokman Shamsudin"), Patimah Ismail"'), and Nakisah Mat Amin"')
}

\begin{abstract}
This study reports the application of Random Amplified Polymorphic DNA (RAPD) technique in establishment of DNA fingerprinting of areolated grouper, Epinephelus areolatus, an economically important fish species of the subfamily Epinephelinae (popularly known as grouper). The RAPD technique was applied to determine the genetic variability within the species for the purpose of implementing and managing its breeding program. Among 20 screened arbitrary primers, six RAPD primers namely OPA-06, OPA-10, OPA-15, OPA 16, OPA-17, and OPA-19 were selected to be used in this study to analyze the RAPD profile, polymorphism, similarity index and genetic distance of $E$. areolatus in the DNA level marker. The results showed that the six primers generated a total of 46 scorable loci (fragments) with $52 \%$ polymorphic loci (24 fragments). The RAPD fragment ranged from two to eight fragments with a size range of 350-3000 bp and the number of genotypes of each primer varied from three to five. Average similarity index among individuals was $0.60156 \pm 0.1045$ and genetic distance level ranged from 0.119 to 0.462 .
\end{abstract}

KEYWORDS: Epinephelus areolatus, DNA fingerprinting, PCR, RAPD

\section{INTRODUCTION}

Areolated grouper, Epinephelus areolatus is one of the important commercial groupers (Epinephelus spp.) caught in the coral reef areas of Southeast Asian countries. It belongs to the subfamily Epinephelinae, and the family Serranidae. Sixty-three species of the genus Epinephelus have been identified by Randall (1987) and at least 21 of them have been reported to have potential for commercial culture as well as a good source of protein (Shamsudin, 1992). E. areolatus is commonly named as aerolated grouper, yellow-spotted rockcod or squaretail rockcod. The body of this species is covered with brownish yellow spots with usually hexagonal in shape on head, body, and fins (sometimes close-set forming a pale meshwork), bigger in size and lighter in shade and the caudal fin is usually emarginate (Kohno et al., 1990). There is little information available on the molecular genetics of this species. Determination of genetic variation of this species on the DNA level marker is necessary to design future management and conservation for its breeding program

Detection of genetic variability is essential to a wide range of comparative genetic endeavors. These include studies as diverse as gene mapping, individual identification, parentage determination, population genetic, molecular phylogenetic, conservation and DNA fingerprinting. Williams et al. (1990) described a novel Polymerase Chain Reaction (PCR) based method called Random Amplified Polymorphic DNA (RAPD) fingerprinting. This technique allows detection of DNA polymorphisms by randomly amplifying multiple regions of the genome by PCR using a single arbitrary primer designed independent of target DNA sequence. DNA fingerprinting is a relatively new technique by which a set of polymorphic markers can be simultaneously detected, resulting in a pattern unique to individual, species, or strain. The RAPD fingerprinting technique has been reported to be extremely efficient for detection of molecular genetic markers in assessment of genetic variation in fish (Dinesh et al., 1993). This technique also has several advantages over other published methods available: (i) a universal set of primers can be used for genomic analyses in a wide variety of species; (ii) no preliminary work, such as isolation of cloned DNA probes, preparation of filter for hybridization, or nucleotide sequencing, is required; and (iii) each RAPD marker is the equivalent of a sequence target site, which can greatly simplify information transfer in collaborative research programs (Williams et al., 1990). The aim of this present study is to establish DNA fingerprinting of areolated grouper, E. areolatus using RAPD analysis.

\section{MATERIALS AND METHODS}

\section{Fish Samples}

Seventeen areolated grouper, $E$. areolatus, with 11. 0-20.4 cm length and 50-186 $\mathrm{g}$ body weight, were

Researcher at Research Institute for Coastal Fisheries, Maros, Indonesia

Lecturers of Faculty of Science and Technology, College Univ. of Science and Technology Malaysia (KUSTEM),

Mengabang, Teliput, 21030, Kuala Terengganu, Malaysia

"m) Lecturer of Faculty of Medicine and Health Science, Universiti Putra Malaysia (UPM), 43400 Serdang, Selangor D.E,

Malaysia. 
collected from South Sulawesi waters. Approximately $50 \mathrm{mg}$ of the muscle tissue was taken out from each individual and placed in a $1.5 \mathrm{~mL}$ microcentrifuge tube containing $250 \mathrm{~mL}$ TNES-Urea preservation buffer. This buffer consists of $6 \mathrm{M}$ urea; $10 \mathrm{mM}$ Tris-HCl; $125 \mathrm{mM}$ $\mathrm{NaCl} ; 10 \mathrm{mM}$ EDTA; and 1\% SDS, at $\mathrm{pH} 7.5$ (Asahida et al., 1996). The samples were transported at ambient temperature from the field and kept at room temperature $\left(25^{\circ}\right.$ to $\left.28^{\circ} \mathrm{C}\right)$ in the laboratory prior to DNA extraction.

\section{DNA Extraction}

Genomic DNA from the muscle tissue was extracted using the Phenol-Chloroform technique. Five hundred microlitres of lysis buffer $(0.5 \mathrm{M} \mathrm{NaCl}, 0.001$ M EDTA, $1 \%$ SDS, $0.8 \%$ Triton $X-100$, and $0.1 \mathrm{M}$ Tris$\mathrm{HCl}$, at $\mathrm{pH} 9.0$ ) was added to the sample and followed by adding $40 \mathrm{~mL}$ SDS $10 \%$ and $40 \mathrm{~mL}$ Proteinase $\mathrm{K}$ (20 $\mathrm{mg} / \mathrm{mL}$ solution). The sample was incubated at $55^{\circ} \mathrm{C}$ for $1-3$ hours until completely lysed. Samples were then treated with $25 \mathrm{~mL}$ RNAase $(20 \mathrm{mg} / \mathrm{mL}$ solution) and left at room temperature $\left(25-28^{\circ} \mathrm{C}\right)$ for 15-30 minutes.

The sample was treated with $500 \mathrm{~mL}$ solvent mixture phenol: chloroform:isoamyl alcohol (25:24:1) and then gently vortexed to homogenize it. The sample was left at room temperature $\left(25-28^{\circ} \mathrm{C}\right)$ for 10 minutes before centrifugation at $13,000 \mathrm{rpm}(11,000 \times \mathrm{g})$ for four minutes. The top aqueous layer was removed to a new $1.5-\mathrm{mL}$ microcentrifuge tube. The step of adding the solvent mixture was repeated twice. The sample was treated with one volume of chloroform : isoamyl alcohol (24:1) and then centrifuged at 13,000 rpm $(11,000 \times \mathrm{g})$ for four minutes. Two volumes of cold absolute ethanol were mixed to the top aqueous layer by inversion of the tubes several times. Precipitated DNA was collected at the bottom of the tubes as a white pellet after centrifugation at $6,000 \mathrm{rpm}(4,000 \mathrm{x}$ g) for 30 minutes. The pellet was washed with one milliliter ethanol $70 \%$ and then centrifuged at 6,000 $\mathrm{rpm}(4,000 \mathrm{xg})$ for 15 minutes. The genomic DNA was allowed to dry at room temperature $\left(25-28^{\circ} \mathrm{C}\right)$ and then resuspended with TE (Tris-EDTA) buffer.

The genomic DNA was electrophoresed in a $0.8 \%$ horizontal agarose gel at 55 volts for $1-2$ hours in $1 x$ TBE (Tris-Borate-EDTA) buffer. The gel was stained with $0.5 \mu \mathrm{g} / \mathrm{mL}$ ethidium bromide for 20-30 minutes and then washed with distilled water for 5-10 minutes prior to photographing

\section{DNA Purity and Quantity}

Ten microliters of genomic DNA were diluted in $490 \mathrm{~mL}$ distilled water (dilution factor of 50 ) in a 0.5 $\mathrm{mL}$ cuvette tube prior to measuring the DNA purity and quantity. Genomic DNA and purity of DNA were estimated using a UVIKON Spectrophotometer (Kontron Instrument) at wavelengths of $260 \mathrm{~nm}$ and $280 \mathrm{~nm}$. The reading of absorbency at $260 \mathrm{~nm}\left(\mathrm{OD}_{260}\right)$ allows calculation of DNA concentration of the sample. The quantity of DNA was quantitatively determined by following the formula of Linacero et al. (1998). Purity of DNA was quantitatively estimated from the ratio between the reading of absorbency at $260 \mathrm{~nm}$ and $280 \mathrm{~nm}\left(\mathrm{OD}_{260} / \mathrm{OD}_{280}\right)$ and also qualitatively observed through the appearance of the single band formed on the agarose gel.

\section{DNA Amplification}

A total of 20 arbitrary primers (OPA01-20) were screened for a randomly single individual in order to find the suitable primer for DNA amplification of grouper. Among them, six primers (based on the clarity and sharpness of the fragments) were selected to use in further analysis (Table 1). DNA amplification reactions consisted of $1 \times$ reaction buffer; $3.5 \mathrm{mM} \mathrm{MgCl}_{2}$;

Table 1. The sequence, nucleotide length, and $G+C$ content of primers used in this study

\begin{tabular}{|c|c|c|c|}
\hline Primer ${ }^{*}$ & Sequences $\left(5^{\prime} \text { to } 3^{\prime}\right)^{\star \star}$ & Nucleotide length & $\mathrm{G}+\mathrm{C}$ content $(\%)$ \\
\hline OPA-06 & GGTCCCTGAC & 10-mer & 70.0 \\
\hline OPA-10 & GTGATCGCAG & 10-mer & 60.0 \\
\hline OPA-15 & TTCCGAACCC & 10-mer & 60.0 \\
\hline OPA-16 & AGCCAGCGAA & 10-mer & 60.0 \\
\hline OPA-17 & GACCGCTTGT & 10-mer & 60.0 \\
\hline OPA-19 & CAAACGTCGG & 10-mer & 60.0 \\
\hline
\end{tabular}


$0.4 \mathrm{mM}$ dNTPs mixture; $0.4 \mathrm{mM}$ primer; 2.0 units taq polymerase; $50 \mathrm{ng}$ template DNA and distilled water in a final volume of $25 \mathrm{~mL}$. The amplification was performed using a programmable temperature cycler of GeneAmp PCR system 2400 from Perkin Elmer. The amplification was programmed at 45 cycles for 30 seconds of denaturation at $94^{\circ} \mathrm{C}, 30$ seconds of annealing at $36^{\circ} \mathrm{C}, 1$ minute of extension at $72^{\circ} \mathrm{C}$, and 2 minutes of final extension at $72^{\circ} \mathrm{C}$.

A mixture of $10 \mathrm{~mL}$ PCR product and $2.5 \mathrm{~mL}$ loading dye was electrophoresed on a $2.0 \%$ horizontal agarose gel at 55 volts for $2-3$ hours and then stained with $0.5 \mathrm{mg} / \mathrm{mL}$ of ethidium bromide for $20-30 \mathrm{~min}$ utes. The gel was washed with distilled water for 510 minutes prior to documentation with Image Master VDS (Pharmacia-Technology).

\section{Data Analysis}

The molecular weight of fragments was estimated based on the standard DNA fragment pattern from GeneRuler DNA ladder marker. The fragments were valued as polymorphic when they are absent in some samples but changes in banding intensity are not considered as polymorphic. Clear fragments were manually scored as present (1) or absent (0) at a particular position or distance migrated on the gel. A data matrix of 1's and 0's was entered into the data analysis package. Data analysis was performed by using the program RAPDistance Package Software Version 1.04 (Amstrong et al., 1994) and Numerical Taxonomy and Multivariate Analysis System (NTSYS) Version 1.80 (Rohlf, 1994). The similarity index of grouper was calculated across all possible pairwise comparisons of individuals using the formula: $S_{x y}=2 n_{x y} / n_{x}+n_{y}$ (Nei and $\mathrm{Li}, 1979$ ). Where $\mathrm{n}_{\mathrm{xy}}$ is the number of fragments shared by individual $x$ and $y ; n_{x}$ and $n_{y}$ are the number of fragments scored for each individual. The index of similarity was used to calculate the genetic distance values and to construct the dendrogram. The dendrogram was constructed using the Unweighted PairGroup Method of Aritmethic (UPGMA) employing Sequential, Agglomerative, Hierarchical and Nested Clustering (SAHN) from NTSYS-pc program (Rohlf, 1994).

\section{RESULTS AND DISCUSSION}

\section{DNA Extraction}

Genomic DNA of $E$. areolatus was successfully extracted by the Phenol-Chloroform technique. The DNA purity and quantity of $E$. areolatus obtained from this technique was $2.0049 \pm 0.1436$ and $67.03 \pm 15.52$ $\mathrm{ng} / \mathrm{mL}$ respectively (Table 2). Linacero et al. (1998) noted that the determination of DNA purity and quantity is an important step in performing a genetic analysis such as RAPD. The purity of genomic DNA should be in the range of 1.8-2.0 for PCR requirement of DNA

Table 2. The purity and quantity of genomic DNA of $E$. areolatus

\begin{tabular}{ccccc}
\hline Ind. Code & $\mathrm{OD}_{\mathbf{2 6 0}}$ & $\mathrm{OD}_{\mathbf{2 8 0}}$ & Purity & Quantity $(\mathrm{ng} / \mu \mathrm{L})$ \\
\hline 1 & 0.0367 & 0.0186 & 1.9731 & 91.75 \\
2 & 0.0176 & 0.0080 & 2.2000 & 44.00 \\
3 & 0.0221 & 0.0110 & 2.0091 & 55.25 \\
4 & 0.0194 & 0.0092 & 2.1087 & 48.50 \\
5 & 0.0271 & 0.0132 & 2.0530 & 67.75 \\
6 & 0.0399 & 0.0196 & 2.0357 & 99.75 \\
7 & 0.0365 & 0.0180 & 2.0278 & 91.25 \\
8 & 0.0287 & 0.0138 & 2.0797 & 71.75 \\
9 & 0.0225 & 0.0103 & 2.1845 & 56.25 \\
10 & 0.0253 & 0.0125 & 2.0240 & 63.25 \\
11 & 0.0282 & 0.0143 & 1.9720 & 70.50 \\
12 & 0.0516 & 0.0318 & 1.6226 & 129.00 \\
13 & 0.0618 & 0.0363 & 1.7025 & 154.50 \\
14 & 0.0448 & 0.0235 & 1.9064 & 112.00 \\
15 & 0.0325 & 0.0156 & 2.0833 & 81.25 \\
16 & 0.0327 & 0.0160 & 2.0438 & 81.75 \\
17 & 0.0461 & 0.0224 & 2.0580 & 115.25 \\
\hline
\end{tabular}

$=$ mean \pm SD 
amplification. However the resuli of this study indicated that the DNA purity of slightly lower than 1.8 and higher than 2.0 showed good RAPD banding patterns. It is necessary to determine the quantity of genomic DNA in order to find out the DNA concentration for optimization of PCR-RAPD analysis.

The high purity level and the clear bands formed on agarose gel of genomic DNA obtained in this study indicated that Phenol-Chloroform is a very powerful technique for DNA extraction in fish especially $E$. areolatus. Using the Phenol-Chloroform technique for routine total DNA isolation. Taggart et al. (1992) obtained a consistently good quality of high molecular weight DNA extracted from 12 species of the genus Salmo, Salvelinus, Oncorhynchus, Coregonus, and Thymalus. Shima (1999) also reported that DNA extraction using the Phenol-Chloroform technique on the mudskipper, Periophthalmus schosseri was more reliable than the DNA extraction of wizard genomic DNA purification kit. The Phenol-Chloroform technique for DNA level extraction was also employed in studies on DNA marker of river catfish, Mystus numerus (Kim, 1998) and tiger barb, Puntius tetrazona (Asma, 1999).

\section{RAPD Profiles}

The RAPD banding patterns were examined for the presence or absence of bands associated with a certain primer used. A set of each 10-mer arbitrary primers of different oligonucleotide sequences was found to generate different RAPD profiles within individuals. Using the six primers, 46 random markers (loci) were generated from DNA amplification of $E$. areolatuis. The RAPD banding patterns from representative samples of $E$. areolatus generated by each primer are shown in Fig. 1.

The number and size of fragments amplified by different primers varied from two to eight and $350-3000$ $b p$, respectively (Table 3 ). The OPA-10 produced the highest number and size of fragments. Asma (1999) also reported the different number and size of fragments revealed by different primers in a study on genetic differences of tiger barb, P. tetrazona. The number and size of amplification products ranged from one to nine fragments and $210-255$ bp respectively. A range of the molecular weight fragments amplified by the four different primers (OPA-14, OPA-17, OPA-18, and OPA-19) on genomic DNA of Malaysian river catfish, Mystus numerus was 200-2000 bp (Lim, 1998).

Different RAPD profiles between two species of groupers have been reported by Bakar \& Azizah (1999). They found that a fragment of $700 \mathrm{bp}$ produced from a primer OPA-05 was present in E. tauvina but not in E. bleekeri. Similar findings were also reported by Williams et al. (1990) and Dinesh et al. (1993). Their results showed that DNA amplification in the fingerprinting technique can be tailored to produce patterns of varying complexity by changing the primer sequence length.

\section{Polymorphism}

Levels of variability were estimated according to the proportion of polymorphic bands within primers

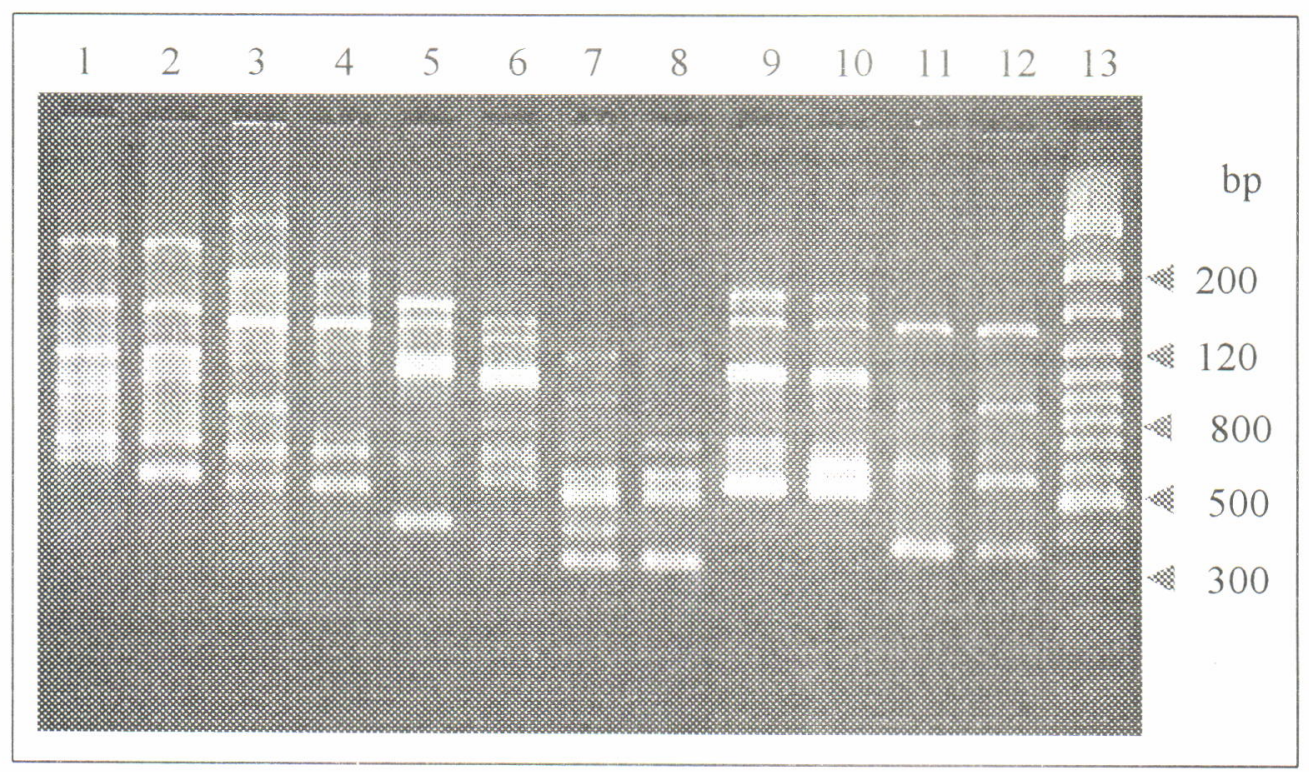

Fig. 1. RAPD banding patterns of the two representative individuals of $E$. areolatus generated by various primers formed on a $2.0 \%$ agarose gel. DNA amplification generated by primers OPA-06 (lanes 1-2), OPA-10 (lanes 3-4), OPA-15 (lanes 5-6), OPA-16 (lanes 7-8), OPA-17 (lanes 9-10), OPA-19 (lanes11-12) and 100bp DNA Ladder Plus from Fermentas (lane 13) 
Table 3. The number and size of fragments amplified by different RAPD primers

\begin{tabular}{ccc}
\hline Primer & Number of fragment & Size range of fragment (bp) \\
\hline OPA-06 & $5-8$ & $400-2500$ \\
OPA-10 & $2-8$ & $550-3000$ \\
OPA-15 & $5-7$ & $350-1600$ \\
OPA-16 & $3-7$ & $350-1200$ \\
OPA-17 & $3-6$ & $550-1600$ \\
OPA-19 & $4-7$ & $350-1600$ \\
\hline
\end{tabular}

(Table 4) and index similarity among individuals (Table 5). Among the primers, the OPA-10 was most variable, having an average of polymorphic bands of $63 \%$. There was considerable variation in the level of polymorphism seen in different primers, ranging from as high as $63 \%$ in OPA- 10 to $44 \%$ in OPA-06. The high polymorphism scored with RAPD markers is probably due to preferential amplification of non-coding repetitive regions of the genome. Since primers are constructed at random, both coding and non-coding regions may be targets of PCR amplification. Lynch and Milligan (1994) noted that the RAPD technique was expected to scan the genomic more randomly than conventional methods. Genotypes obtained in each primer varied from three to five in percentage ranging from $5.9 \%$ to $58.8 \%$. The highest genotype number was revealed by primer OPA-10 and the lowest by primer OPA-16. The high genotype observed indicated the great genetic variability of this species.

A high level of diversity ranging from $33.33 \%$ to $50.00 \%$ was detected in the freshwater shrimp,
Macrobrachium borellii with the RAPD marker (D'Amato and Corach, 1996). Different species of tilapine fishes showed different polymorphic bands (Mwanja et al., 1996). The results of their investigation on five species of tilapia showed that the number of polymorphic bands was $49 \%$ to $81 \%$ (Oreochromis niloticus), $33 \%$ to $78 \%$ (O. esculentus), $64 \%$ to $78 \%$ (O. leocostictus), $70 \%$ (Sarotherodon galilaeus), and $55 \%$ to $75 \%$ (Tilapia zilli).

\section{Similarity Index and Genetic Distance Level}

The similarity index among individuals of $E$. areolatus ranged from $0.4137-1.0000$ with an average of $0.60156 \pm 0.1045$ (Table 5). The similarity index of 1.000 indicated that individuals showed the genetic identical such as individual between 1 and 4 ; and 2 and 7 . The similarity index was found to be lowest $(0.4137)$ between individual 10 and 12 . The similarity index of tiger barb, P. tetrazona varied from 0.62778 0.73131 in Perak population and 0.33333-0.83222 in Johor population (Asma, 1999).

Table 4. Total number of fragments (TF), number of polymorphic fragments (PF), and proportion of polymorphic fragments (PPF), number and percentage of genotypes of $E$. areolatus

\begin{tabular}{lcccccc}
\hline & OPA-06 & OPA-10 & OPA-15 & OPA-16 & OPA-17 & OPA-19 \\
\hline TF & 9 & 8 & 8 & 7 & 6 & 8 \\
PF & 4 & 5 & 4 & 4 & 3 & 4 \\
PPF & 0.44 & 0.63 & 0.5 & 0.57 & 0.5 & 0.5 \\
No.Genotype & 4 & 5 & 4 & 3 & 4 & 4 \\
Percentage of & $47.1(8)$ & $35.3(6)$ & $47.1(8)$ & $58.8(10)$ & $47.1(8)$ & $58.8(10)$ \\
Genotype* $^{*}$ & $23.5(4)$ & $29.4(5)$ & $23.5(4)$ & $35.3(6)$ & $29.4(5)$ & $17.6(3)$ \\
& $17.6(3)$ & $17.6(3)$ & $17.6(3)$ & $5.9(1)$ & $17.6(3)$ & $11.8(2)$ \\
& $11.8(2)$ & $11.8(2)$ & $11.8(2)$ & & $5.9(1)$ & $11.8(2)$ \\
& & $5.9(1)$ & & & & \\
\end{tabular}

${ }^{\star}()=$ number of individuals 
Figure 2 shows the dendrogram of seventeen individuals of $E$. areolatus constructed according to the genetic distance from Nei and Li's indices. The genetic distance level obtained ranged from 0.119 to 0.462 . A high level of genetic distance of this species indicated a low level of inbreeding among individuals. It is also supported by the fact that the samples were collected from a wild population. On the other hand, the low genetic distance, indicating the high inbreeding activity level, has been reported for several cultivable fishes such as tiger barb, tilapia, discus and hilsa shad. Asma (1999) found a low genetic distance level on domesticated tiger barb, $P$. tetrazona among individuals of different varieties and populations. The genetic distance values ranged from 0.048 to 0.294 in normal variety from Perak population, 0.032 to 0.833 in green variety from Perak population, 0.030-0.286 in yellow variety from Perak population, 0.043 to 0.529 in normal variety from Johor population, 0.033 to 0.304 in green variety from Johor population, and 0.034 to 0.429 in yellow variety from Johor population. The different genetic distance on different fish species has been shown on tilapia (Bardakci and Skibinski, 1999), discus (Koh et al., 1999) and hilsa shad (Dahle et al.,
1997) where the genetic distance was $0.04-0.34,0.07-$ 0.18 and $0.08-0.16$, respectively.

\section{CONCLUSION}

A total of 46 loci (fragments) with $52 \%$ polymorphic fragments in size length of 350-3000 bp and three to five genotypes of $E$. aerolatus were generated by the six primers. The high genetic distance level observed in this species indicates a low inbreeding activity among individuals. The RAPD demonstrated a useful technique in detection of polymorphism and generating a potential analysis for DNA fingerprinting of fish species.

\section{ACKNOWLEDGEMENT}

The authors would like to thank the Agency for Agricultural Research and Development (AARD) of Indonesian Government for financial support of this research under the Agricultural Research Management Project (ARMP phase II). The authors also thank to Dean of Faculty of Science and Technology and Dean of Faculty of Medicine and Health Science, University Putra Malaysia (UPM) for providing the facilities for

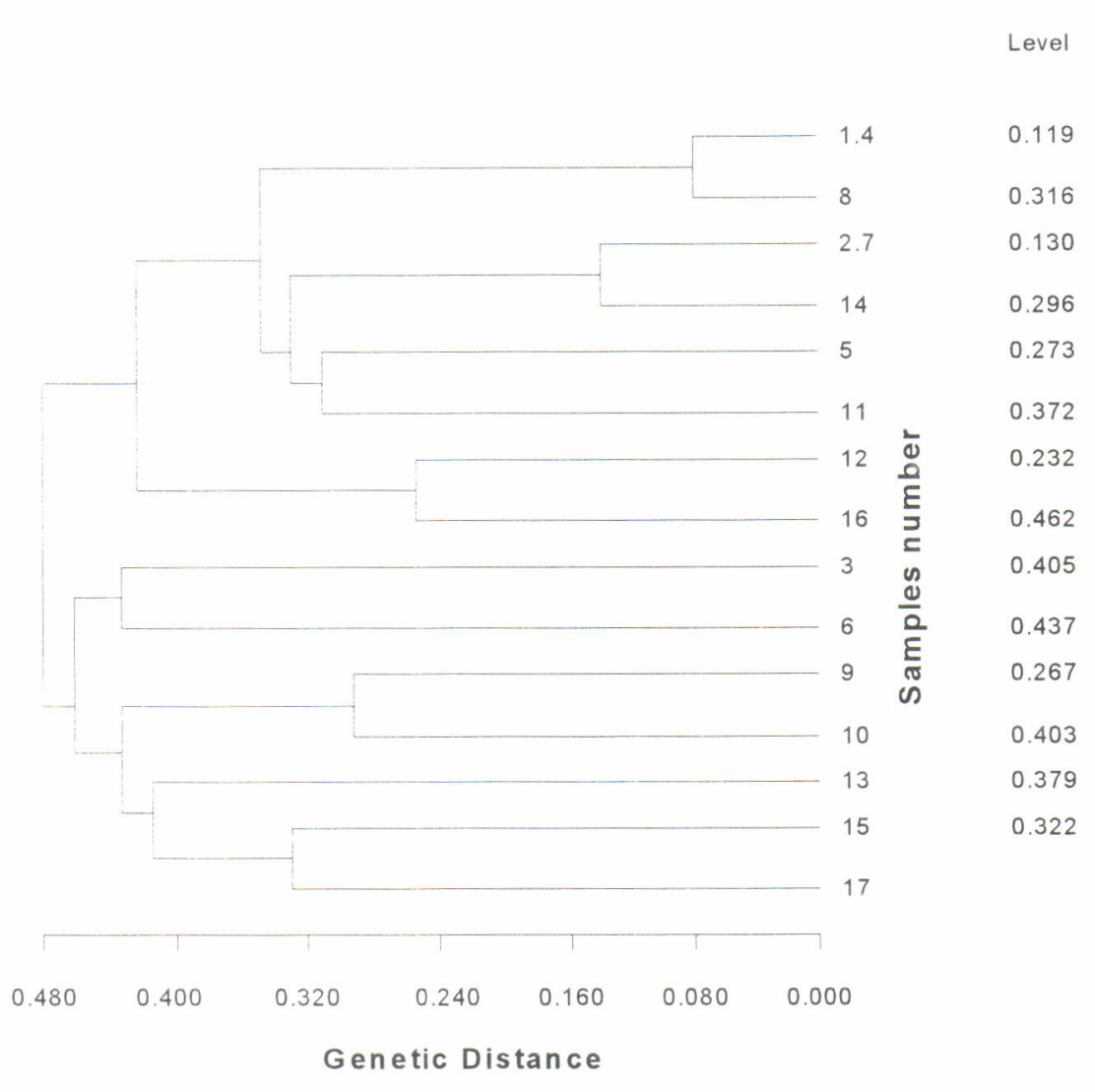

Fig. 2. UPGMA cluster analysis based on the genetic distance generated from Nei and Li's indices of $E$. areolatus 


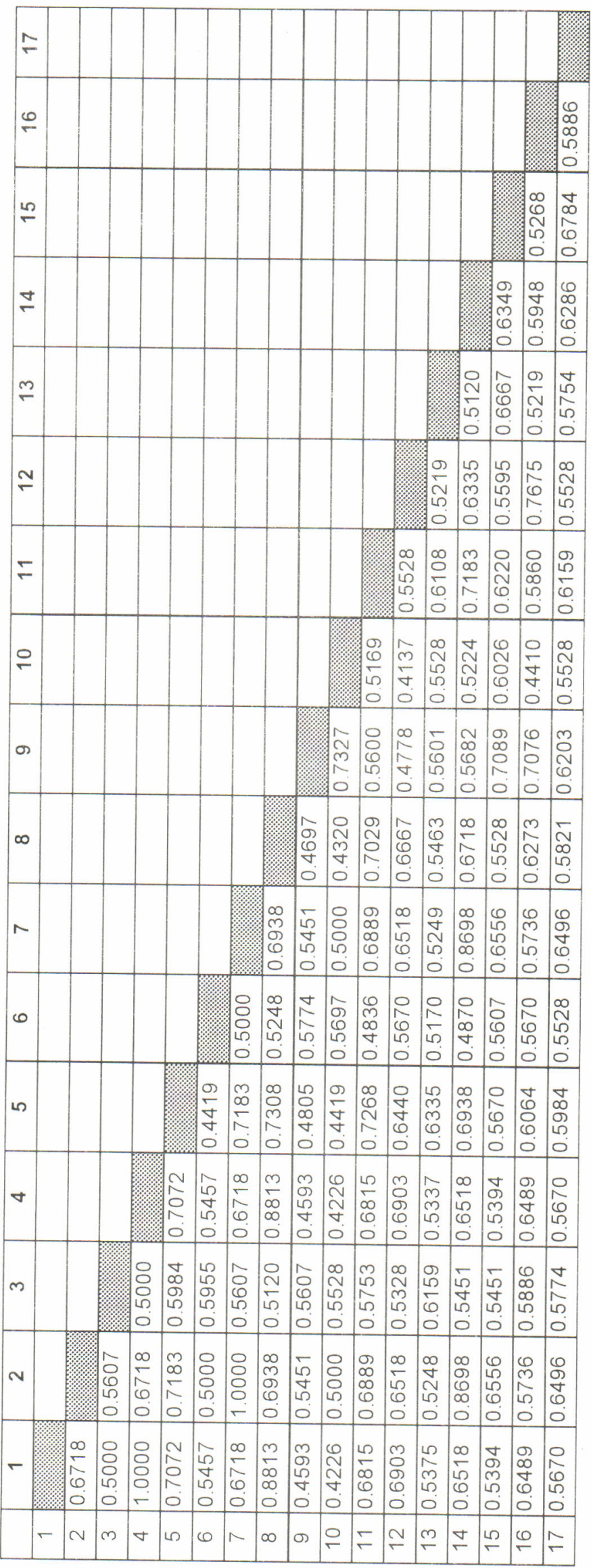


this research. The authors wish to express their gratitude to Abdul Khalik, Syafrizal, Joni Haryadi, Halim Yahya, Rozihan, Norazila, Wan Bayani, Nazlin, Ruzainah, and Joseph Maripa Raja for their assistance in this study.

\section{REFERENCES}

Amstrong, J.S. A.J. Gibbs, R. Peackall, and G. Weiller 1994. The RAP Distance Package. Http //life anu.aul molecular/software/rapd.html.

Asahida. T. T. Kabayashi, K. Saitoh, and I. Nakayama. 1996. Tissue preservation and total DNA extraction from fish store at ambient temperature using buffer containing high concentration of urea. Fisheries Science 62(5): 727--730

Asma. N. A 1999. Genetic Variation Between and Within Three Varieties of Domesticated Tiger Barb (Puntius tetrazona) using RAPD Markers. Thesis Faculty of Medicine and Health Sciences, Universiti Putra Malaysia. $115 \mathrm{pp}$

Bakar, A and S. Azizah. 1999. RAPD fingerprinting of two species of the grouper, Epinephelus off the coast of Pulau Pinang. Paper Presented at Tropical Fisheries and Aquaculture Conference, 5--7 September 1999, Primula Park Royal, Kuala Terengganu, Malaysia, 9 $\mathrm{pp}$

Bardakci, F and D. O.F. Skibinski. 1999. A polymorphic SCAR-RAPD marker between species of tilapia (Pisces:Cichlidae). Animal Genetic (30): 78--79

Dahle, G., M. Rahman, and A.G. Eriksen. 1997. RAPD fingerprinting used for discriminating among three populations of hilsa shad (Tenualosa ilisha). Fisheries Research 32: 263--269.

D'Amato, M.E. and D. Corach. 1996. Genetic diversity of population of the fresh-water shrimp Macrobrachium borellii (Caridae:Palaemonidae) evaluated by RAPD analysis. J. Crustacean Biol. 16(4): 650--655

Dinesh. K.R., T.M. Lim, K.L. Chua, W.K. Chan, and V.P.E. Phang. 1993. RAPD analysis: an efficient method of DNA fingerprinting in fisheries. Zoological Sci. 10 : 849--854.

Kim, C.L. 1998. Development of PCR-based DNA Markers to Identify and Characterise Malaysian River Catfish, Mystus nemurus (C\&V): RAPD and AFLP. Thesis Master of Science, Faculty of Science and Environmental Studies, Universiti Putra Malaysia, $124 \mathrm{pp}$.

Koh, T.L., G. Khoo, L.Q. Fan, and V.P.E. Phang. 1999. Genetic diversity among wild forms and cultivated varieties of discus (Symphysodon spp.) as revealed by Random Amplified Polymorphic DNA (RAPD) fingerprinting. Aquaculture 173: 485--497

Kohno, H. M. Duray, and P. Sunyoto. 1990. A Field Guide to Groupers of Southeast Asia. Central Research institute for Fisheries and Japan International Cooperation Agency. Jakarta. $26 \mathrm{pp}$.

Lim, F.T. 1998. Molecular Polymorphisms Studies of Malaysian River Catfish, Ikan Baung (Mystus nemurus), Detected using the RAPD-PCR Method. Thesis of Faculty of Science and Environmental Studies, Universiti Putra Malaysia, Serdang, 88 pp

Linacero, R., J. Rueda, and A.M. Vazquez. 1998. Quantification of DNA. In: Karp, A., Isaac, P.G. and Ingram D.S. (Eds.) Molecular Tools for Screening Biodiversity Plants and Animals, p: 18--21

Lynch, M. and B.G. Milligan. 1994. Analysis of population genetic structure with RAPD markers. Molecular Ecol. 3: $91--99$

Mwanja, W., G.C. Booton, L. Kaufman, M. Chandler, and P. Fuerst. 1996. Population and stock characterization of Lake Victoria tilapine fisher based on RAPD markers. Aqua. Biotech. Symp. Proceeding, p.115-123

Nei, M. and W. Li. 1979. Mathematical model for studying genetic variation in terms of restriction endonucleases. Proceeding of the National Academic of Science, USA. 76: 5269--5273.

Randall, J.E. 1987. A premilinary synopsis of the grouper (Perciformis: Serrinidae:Epinephelinae) of IndoPacific Region. In: Polovina, J.J. and S.Ralston (Eds.) Tropical Snapper and Groupers: Biology and Fisheries Management. p: 89--169.

Rohlf, F.J. 1994. NTSYS-pc Numerical Taxonomy and Multivariate Analysis System. Exeter Software. New York.

Shamsudin, L. 1992. Akuakultur Pinggir Laut. Dewan Bahasa dan Pustaka, Kuala Lumpur. 395 pp.

Shima, T.I.S. 1999. PCR-RAPD Analysis on DNA of Mudskipper, Periphthalmus schlosseri (Pallas). Faculty of Applied Science and Technology, Universiti Putra Malaysia, $62 \mathrm{pp}$

Taggart, J.B., R.A. Hynes, P.A. Prodohl, and A. Ferguson. 1992. A simplified protocol for routine total DNA isolation from salmonid fishes. J. Fish Biol., 40: 963-965.

Williams, J.G.K., A.R. Kubelik, K.J. Livak, J.A. Rafalski, and S.V. Tingey. 1990. DNA polymorphisms amplified by arbitrary primers are useful as genetic marker. Nucleic Acids Research 18: 6531. 